\title{
SYMBICORT SMART - PAŽANGUS METODAS SIEKTI ASTMOS KONTROLĖS
}

\author{
DOC. DR. BRIGITA ŠITKAUSKIENE \\ KMU PULMONOLOGIJOS IRIMUNOLOGIJOS KLINIKA
}

Reikšminiai žodžiai: astmos kontrolè, paūmėjimai, palaikomasis ir simptomus slopinantis gydymas.

Santrauka. Pagrindinis astmos gydymo tikslas, t. y. astmos kontrolè, pasiekiamas gerinant klinikinių ligos simptomų valdymą ir kartu mažinant paūmèjimų riziką. Klinikinių tyrimų duomenys rodo, kad taikant palaikomajji ir simptomus slopinanti gydymą vienu inhaliatoriumi - budezonido ir formoterolio deriniu (Symbicort SMART) - suaugusiems pacientams, sergantiems vidutinio sunkumo ar sunkia astma, pavyksta geriau kontroliuoti ligą nei gydant ịprastiniu būdu: vien inhaliuojamaisiais gliukokortikosteroidais arba inhaliuojamaisiais gliukokortikosteroidais ir ilgai veikiančiu beta 2 agonistų fiksuota doze, 0 simptomus slopinant trumpai veikiančiais beta 2 agonistais.

Sergamumas astma sparčiai dideja visame pasaulyje, taip pat ir Lietuvoje. Šiuo metu pasaulyje astma diagnozuota maždaug 300 milijonų žmonių, Lietuvoje 4-6 proc. gyventojų. Atsižvelgiant ì sergamumo didèjimo tendencijas, manoma, kad iki 2025 m. sergančiuc astma skaičius padidès dar 100 milijonų.

Pagrindinis visuotinai priimtas šiuolaikinis astmos gydymo tikslas - pasiekti ir išlaikyti astmos kontrolę. "GINA“ rekomendacijos gerai kontroliuojamą astmą apibrèžia taip: nėra varginančių simptomų nei dieną, nei naktį, simptomus slopinančius vaistus pacientas vartoja retai arba iš viso nevartoja (jų neprireikia), plaučių funkcija artima normaliai, nèra sunkių paūmejjimų, dèl kurių pacientą reikètu gydyti ligonineje arba skubiosios pagalbos skyriuje. Visiška astmos kontrolè pasiekiama ir gerinant esamą klinikinę ligos kontrolę, ir kartu mažinant astmos paūmẻjimų, galinčiu išsivystyti ateityje, riziką.

Svarbiausias astmos patofiziologinis mechanizmas nuolat persistuojantis uždegimas, kuris epizodiškai paūmèja ir lemia tolydžio blogèjančią plaučių funkciją. Šiuo metu veiksmingiausi vaistai astmos uždegimui gydyti - inhaliuojamieji gliukokortikosteroidai (IKS), skirtini palaikomajam gydymui. Jei gydant mažomis ar vidutinėmis IKS dozėmis nepavyksta kontroliuoti astmos, rekomenduojama taikyti gydymą IKS ir ilgai veikiančių beta 2 agonistų (IVBA) deriniais. Dažniausiai naudojami du fiksuotu dozių deriniai: salmeterolis ir flutikazonas (Seretide); budezonidas ir formoterolis (Symbicort). Abu deriniai simptomų, plaučių funkcijos ir paūmèjimų požiūriu yra veiksmingesni už gydymą vien tik IKS, nors ir dvigubai didesne doze. Greta astmos palaikomojo gydymo kontroliuojamuoju vaistu, esant reikalui, pacientui skiriami ir simptomus šalinantys vaistai, paprastai trumpai veikiantys beta 2 agonistai (TVBA), kurie greitai mažina bronchų konstrikciją ir simptomus. Padidèjęs simptomus slopinančių preparatu poreikis rodo, kad ligos kontrolè blogèja ir reikia intensyvinti palaikomąji uždegimo gydymą.

FACET tyrimas (A. E. Tattersfield ir kt.), kuriame buvo atlikta 425 sunkių astmos paūméjimų analizè, parodè, kad 5-7 dienas prieš paūmèjimą pacientas jaučia ankstyvuosius ispeejamuosius simptomus, pavyzdžiui, didesnị dusuli ir poreiki vartoti daugiau TVBA. Šiuo "galimybių lango" laikotarpiu paskirta ar padidinta IKS dozè slopintų uždegimą ir būtų galima išvengti simptomų intensyvèjimo bei paūmèjimo (1 pav.).

Didelių klinikinių atsitiktinių imčių tyrimų, kuriais buvo lyginti iprastiniai gydymo metodai su palaikomuoju ir simptomus slopinančiu gydymu budezonido ir formoterolio deriniu (Symbicort SMART), duomenimis, visose tiriamųju grupèse astmos simptomų kontrolè bei plaučių funkcijos pagerẻjimas esti vienodai geras, tačiau, gydant SMART metodu, toks rezultatas pasiekiamas vartojant mažesnę IKS dozę (2 pav.). SMART metodo pranašumas tas, kad palaikomasis ir simptomus slopinantis gydymas budezonido ir formoterolio deriniu, palyginti su fiksuotomis, nors ir didesnemis dozemis IKS ir IVBA bei TVBA simptomams slopinti, veiks- 
mingiau mažina sunkių paūmèjimų dažnumą (3 pav.). AHE$\mathrm{AD}$ klinikiniu tyrimu nustatyta, kad, palyginti su gydymu, kai vartojama didžiausia astmai gydyti patvirtinta salmeterolio ir flutikazono dozè, palaikomasis ir simptomus slopinantis gydymas budezonido ir formoterolio deriniu sumažino bendrą paūmèjimų dažnumą 21 proc., taip pat sumažejo gydymo nuo astmos ligoninejje ir skubiosios pagalbos skyriuje dažnumas, reikšmingai sumažèjo geriamųju gliukokortikosteroidų, skiriamų paūmèjimams gydyti, poreikis. Taikant palaikomąji ir simptomus slopinanti gydymą budezonidu ir formoteroliu, astma geriau kontroliuojama vartojant mažiau gliukokortikosteroiduc negu gydant fiksuotomis salmeterolio ir flutikazono, budezonido ir formoterolio dozèmis bei TVBA.

Taigi klinikinių tyrimų rezultatai rodo, kad vartojant budezonido ir formoterolio derini (Symbicort) nuolatiniam astmos gydymui ir simptomams slopinti (SMART metodu), pavyksta sẻkmingai igyvendinti pagrindinius astmos gydymo tikslus, nurodytus GINA rekomendacijose ir Lietuvos vaikų bei suaugusiųjų astmos diagnostikos ir gydymo 2007 metų susitarime:

- pasiekti ir palaikyti simptomų kontrolę;

- palaikyti normalų aktyvumą (įskaitant fizinio krūvio toleravimą);

- palaikyti plaučių funkciją, kad ji būtų kuo artimesnè normaliai;

- apsaugoti nuo astmos paūmèjimų;

- išvengti nepageidaujamo astmos gydymo preparatuc poveikio;

- apsaugoti nuo astmos lemiamų mirčiuc.

O svarbiausia, kad, taikant palaikomąji ir simptomus slopinantị gydymą budezonidu ir formoteroliu, būna mažiau sunkių paūmèjimų vartojant mažesnes IKS dozes.

SMART metodui pritaria ir "GINA“. Palaikomasis ir simptomus slopinantis gydymas budezonidu ir formoteroliu yra vienintelis gydymo būdas IKS ir IVBA deriniu, kuri "GINA“ rekomenduoja taikyti pacientams, sergantiems vidutinio sunkumo ar sunkia astma, kai ligos nepavyksta kontroliuoti vien tik IKS.

Gydant Symbicort SMART metodu, rekomenduojama palaikomoji dozė yra dvi inhaliacijos per dieną (160 ir 4,5 $\mu \mathrm{g}$ budezonido/formoterolio vienoje), jei reikia, preparato ¡kvèpiant papildomai. Sunkiau sergantiems ligoniams galima skirti dviejų inhaliacijų du kartus per dieną palaikomąją dozę. Palaikomasis ir simptomus slopinantis astmos gydymas budezonidu ir formoteroliu yra paprastesnis, priimtinesnis, nes naudojamas vienas inhaliatorius, taigi pacientai turètu geriau laikytis gydymo nurodymų.

SYMBICORT SMART - A PROGRESSIVE METHOD GAINING ASTHMA CONTROL

\section{BRIGITA ŠITKAUSKIENE \\ DEPARTMENT OF PULMONOLOGY AND IMMUNOLOGY KAUNAS UNIVERSITY OF MEDICINE}

Keywords: asthma control, exacerbations,maintenance and reliever therapy. Summary: The main goal of asthma management - asthma control - is achieved by improving both current clinical control and reducing the future risk of asthma exacerbations. Clinical trials show that asthma control is significantly improved by budesonide/formoterol maintenance and reliever therapy in adults with moderate to severe asthma compared with conventional therapies consisting of an ICS or ICS/LABA plus SABA for relief.

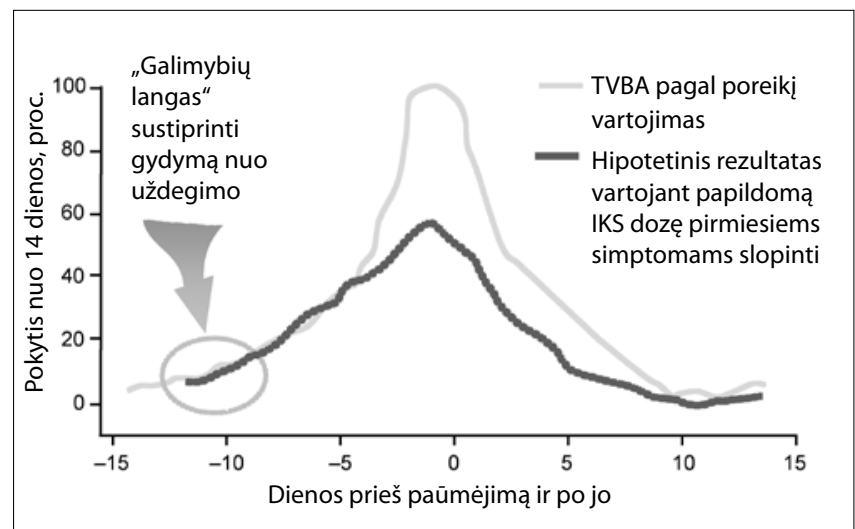

1 pav. "GALIMYBIŲ LANGAS" APSAUGOTI NUO ASTMOS PAŪMĖJIMO (PAGAL A. E. TATTERSFIELD IR KT.)

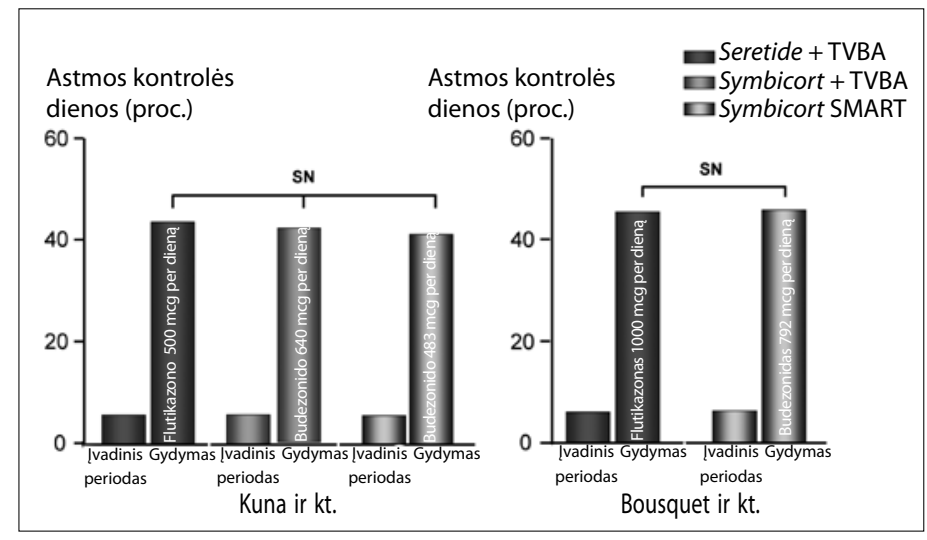

2 pav. ASTMOS SIMPTOMŲ KONTROLĖ VIENODAI GERA VISOSE GYDYMO GRUPÉSE

Symbicort SMART grupejje toks rezultatas pasiektas mažesne IKS doze.

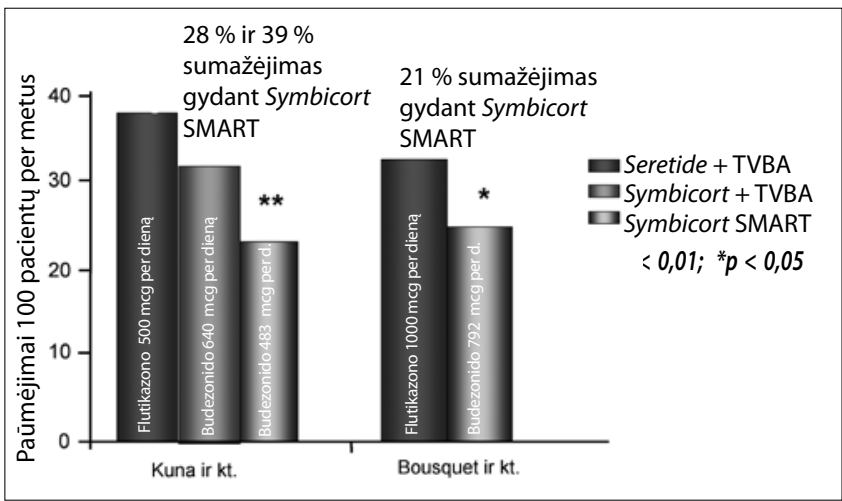

3 pav. MAŽIAU SUNKIŲ ASTMOS PAŪMĖJIMŲ GYDANT SYMBICORT SMART Symbicort SMART grupeje toks rezultatas pasiektas mažesne IKS doze.

\section{LITERATŪRA}

1. Global Initiative for Asthma. Global strategy for asthma management and prevention - updated 2007. Available at: www.ginasthma.com. Accessed July 26, 2007.

2. Sakalauskas $R$, Bagdonas $A$, Blažienè A irk t. Lietuvos vaikų ir suaugusiuju astmos diagnostikos ir gydymo sutarimas. Kaunas, 2007.

3. Šitkauskiené B. Astmos kontrolè vienu inhaliatoriumi - nauja astmos gydymo strategija. Pulmonologija, imunologija ir alergologija 2007; 2:5659.

4. Bateman ED, Boushey HA, Bousquet J, et al. Can guideline-defined asthma control be achieved? The Gaining Optimal Asthma ControL study. Am J Respir Crit Care Med 2004; 170:836-844.

5. Bai TR, Vonk JM, Postma DS, et al. Severe exacerbations predict excess lung function decline in asthma. Eur Respir J 2007; 30:452-456.

6. Rabe KF, Adachi M, Lai CK, et al. Worldwide severity and control of asthma in children and adults: the global asthma insights and reality surveys. J Allergy Clin Immunol 2004; 114:40-47.

7. Barnes PJ. Scientific rationale for using a single inhaler for asthma control. Eur Respir J 2007; 29:587-595.

Kiti literatūros šaltiniai - redakcijoje (iš viso 10). Straipsnio publikaciją remia AstraZeneca. 